症例

腹腔内腫瘤にて発見された十二指腸球部粘液癌の 1 例

\author{
マツダ病院外科, 西条中央病院外科* \\ 加 納 幹 浩 村下 純 二*
}

症例は83歳の男性，右側腹部痛を主訴として来院し，十二指腸潰瘍として保存的加療 が行われた．入院時 CTにて腹腔内に腫留がみられた。症状の軽減がみられず，上部消 化管内視鏡再検査が施行された. 十二指腸球後部における隆起性の周堤を伴う難治性潰 痬性病変から生検組織にて adenocarcinoma と診断された。手術所見は十二指腸球部か ら下行脚上部に限局した壁外へ隆起した腫瘤を認め, 十二指腸部分切除術を施行した。 切除標本では球部から下行部に Borrmann II 型の外観を呈する粘液を有する腫瘍を認 めた。病理組織学検査は辺緑に adenocarcinoma を伴った, 主体は細胞外粘液産生の多 い mucinous carcinoma であった．原発性十二指腸癌は比較的稀であり，なかでも壁外 へ隆起した粘液癌であり, 形態学的に珍しいものであった.

索引用語：十二指腸球部癌, 粘液癌

\section{緒 言}

原発性十二指腸癌は比較的稀であり, 全消化器癌の

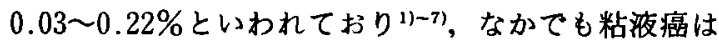
発生頻度が低い，今回われわれは，腹腔内腫瘤として 発見された十二指腸球部粘液癌の 1 症例を経験し, 興 味ある症例と考えられたため文献的考察を加えて報告 する。

\section{症例}

症例：83歳, 男性.

主訴：右側腹部痛.

既往歴：高血压.

現病歴：平成14年10月末より，数日間持続する右腹 部痛が出現したため, 当院内科を受診した，初診時, 貧血, 黄㾝などは認めなかったが, 右季肋部から右側 腹部に圧痛を認め, 精査加療目的で入院となった。

入院時検査成績 : WBC $9,200 / \mu \mathrm{l}, \mathrm{Hb} 14.0 \mathrm{~g} / \mathrm{dl}$, 腫 湯マーカーは CEA 2.9ng/ml, CA19-9 7.8U/ml と正 常値であった。

入院時腹部 CT：腹腔内に内部不均一な腫瘤像を認 めた（図 1 ).

また上部消化管内視鏡検査にて十二指腸球後部に辺

2005 年 4 月 5 日受付 2005 年 6 月15日採用

〈所属施設住所〉

₹735-8585 広島県安芸郡府中町青崎南 2-15
縁不整の潰瘍性病変を認めたが，壁内への発育は軽度 で, 腸管腔内の通過障害は認められなかった，以上よ りまず十二指腸潰瘍と溃瘍穿孔による牫存膿瘍と考 え,プロトンポンプインヒビターと抗菌薬を投与され た、しかし 3 週間経過しても症状の軽快は諗められず， 悪性病変を疑い, 再検査を行った。

上部消化管造影：球部に内腔へ軽度に隆起した周堤 を伴う陥凹性病変を認めた（図 2 ）。

消化管造影直後 CT 検査：十二指腸球部壁に隆起性 の不正な腫瘤像が認められた（図 3 ).

上部消化管内視鏡検査：潰煌周堤の隆起がみられ

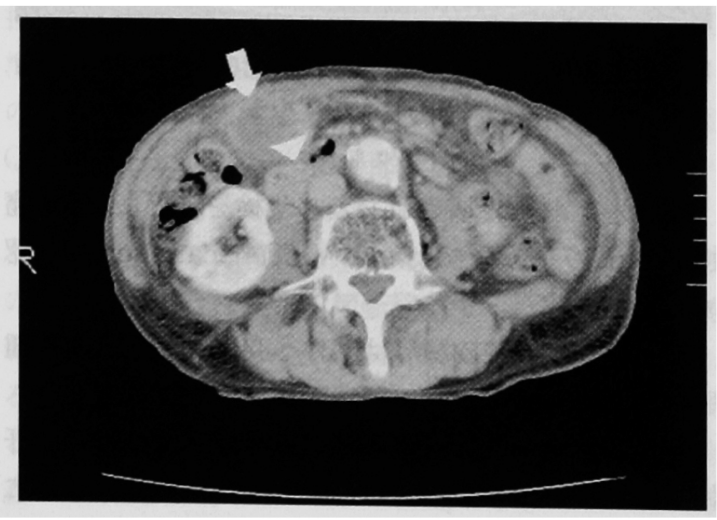

図 1 入院時腹部 $\mathrm{CT}$ 検査：内部不均一な低吸収域を認 める(矢印)。内側に ( $\Delta$ 印) 十二指腸下行脚を認める。 


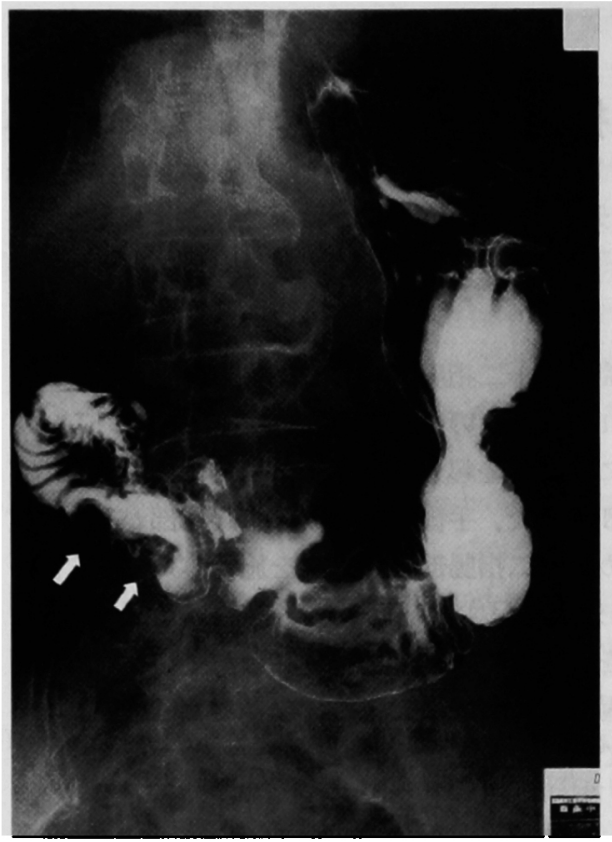

図 2 上部消化管造影検査：十二指腸球部に内 腔へ軽度隆起した謴癌病変みられる (矢印).

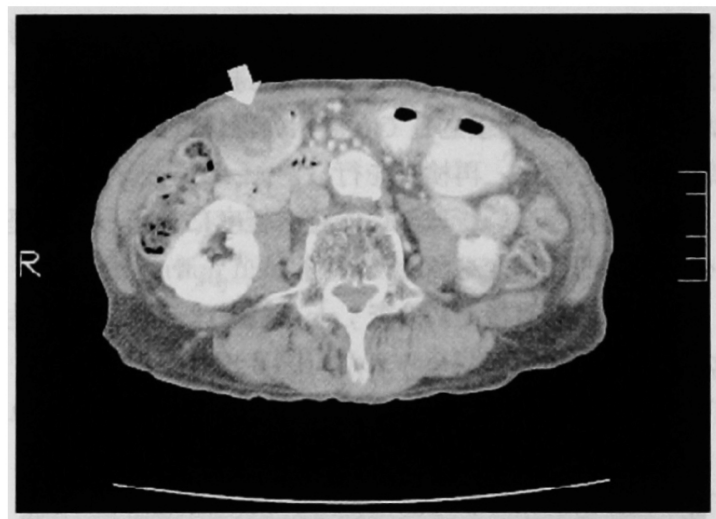

図 3 造影後 CT 検査：十二指腸球部壁に内側外側に向 かって隆起した腫瘤陰影像を認める(矢印)。

(図 4), 悪性が示唆されたため生検を施行した. 潰瘍 性病変部の生検にて group V adenocarcinoma を認 めた。

以上ょり, 腹腔内腫瘤は壁外へ突出した十二指腸腫 瘍と診断し，治療目的にて12月16日手術を行った。

手術所見：上腹部正中切開にて開腹した。腹水，肝 転移，腹膜播種などは認められなかった。腫瘍は十二 指腸球部から下行脚上部に限局した壁内外へ突出した 腫瘤であり，腹腔内には軽度の炎症性痛着がみられた

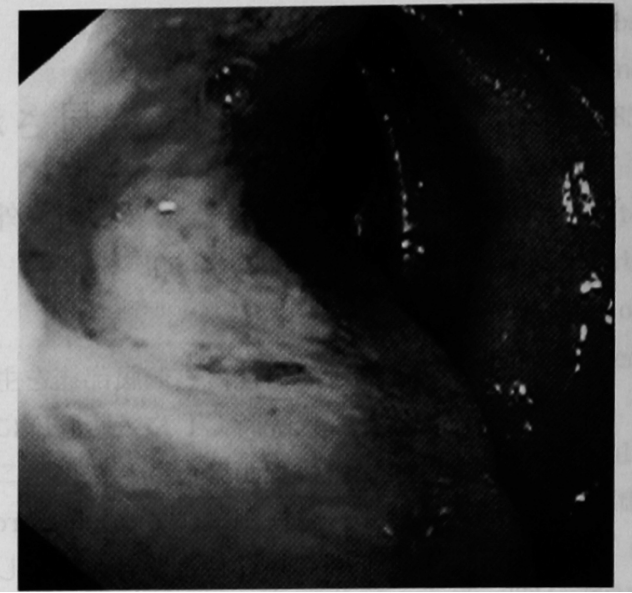

図 4 上部内視鏡検査：球部前壁に周堤をもつ 不正形な謴瘍を認める。

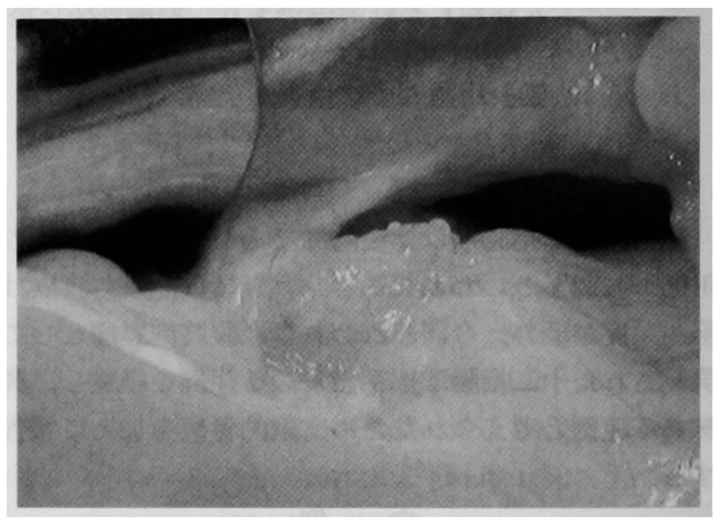

図 5 術中所見：球部前壁より，突出した腫㨨がみられ る.

ものの，可動性があった(図 5)。このため当初は根治 的に膵頭十二指腸切除も考慮に入れていたが，高齢で あり本人の手術に対する体力的な問題に加えて, 部位 的に乳頭部から十分離れているため，十二指腸部分切 除術を選択した。胃幽門部から乳頭部を損傷しない可 能なかぎり十二指腸肛門側で腫瘍より $10 \mathrm{~mm}$ 離して切 断，郭清は幽門側胃切除における 1 群郭清と 12, 13， 17 番リンパ節の部分的郭清を行った。再建は Billroth II法にて行った。

摘出標本 : $4.5 \times 4.0 \mathrm{~cm}$ の周堤の低い Borrmann II 型の腫瘤を認め, 壁外への大きな進展がみられたが, 明らかな周囲組織浸潤はみられず，また腸管腔内への 発育は軽度であった（図6)，腫瘍割面には無色ゼリー 状の粘液成分が占めていた。 


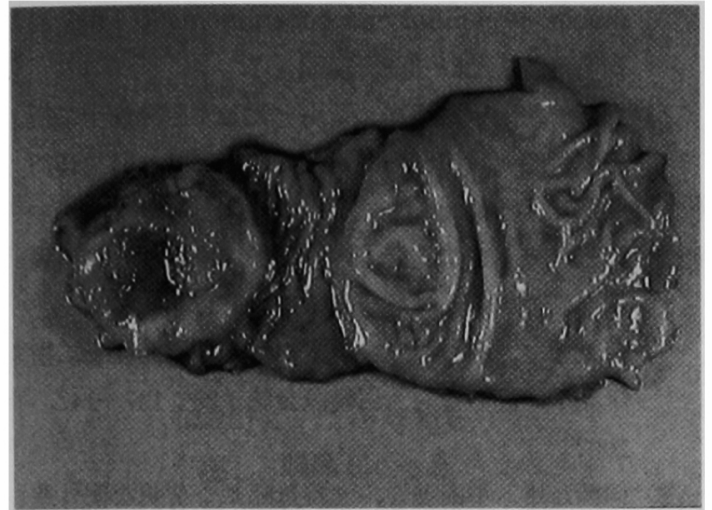

図 6 固定切除標本：内部に粘液をもつ潰瘍形態の腫瘍 を認める(固定後のため粘液が脱落し, 腫瘍が退縮して いる).

病理組織学検査: 辺縁に adenocarcinoma を伴っ た, 主体は細胞外粘液産生の多い mucinous carcinoma であった（図 7 )。口側, 肛門側ともに断端陰 性であったが, 媣達度は槳膜への露出がみられた。ま たNo.12b のリンパ節に転移を認めた.

術後経過：良好にて術後27日に退院となった。術後 補助化学療法は行わな⿰力た。術後 1 年後の CT に扔 いては再発の徴候は認められておらず，現在再発の兆 候なく術後より 2 年経過している.

\section{考 察}

原発性十二指腸癌は比較的稀な疾患である.しかし， 近年内視鏡検査の普及とともに本邦でも報告例が増加 しており, 早期癌だけでなく十二指腸進行癌の報告も 增加しているい

臨床症状は腹痛, 心窩部痛, 腹部不快感などの十二 指腸潰瘍と同様な症状が約 7 割にみられるとされ $ろ^{2)}$. また, 腫㿠の発生部位は解剖学的に十二指腸を第 $1 \sim 4$ 部まで分類すると第 1 - 2 部つまり乳頭上部の ものが多いとされ゙, 最近では, 球部においてまとめら れた報告が散見される233. 自験例は来院当初, 胃内視 鏡検査にて潰瘍病変と診断され, プロトンポンプイン ヒビターを内服投与された。潰瘍好発部位であったこ とから, CT による腫瘤は十二指腸潰瘍病変の残存膿 瘍と考えた，経過観察にて，軽快がみられないため， さらに精査を行うことになったわけだが，良性疾患の 多い十二指腸球部の潰瘍性病変に対する悪性疾患の存 在を念頭におき，生検などの診断は可能な限り必要と 考えられた。

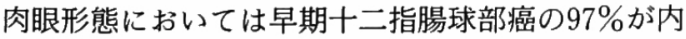

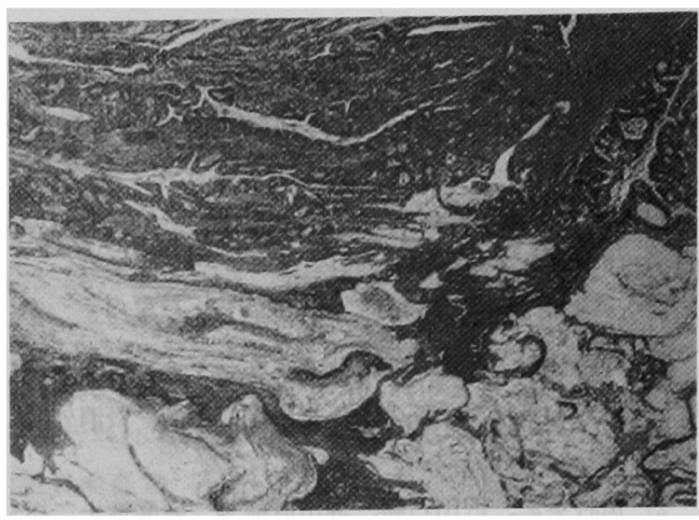

図 7 病理組織学的所見 (H.E.染色, 40倍)：周 囲に adenocarcinoma を伴った, mucinous carcinoma を 認めた。

腔への隆起型という報告があるが2)，いわゆる進行癌 は形態として異なり，陥凹潰㰾型が優勢とされる213). また粘液癌に扔いて, 壁外進展など特異な進展傾向を 有することが大腸において報告されているが8), 医学 中央雑誌に掲載された乳頭部以外の粘液癌 4 症例の報 告のうち ${ }^{3) \sim 6)}, 3$ 例は潰湯浸潤型を呈しており，3 例に 膵への浸潤を認めるが, 壁外への突出は 4 例とも認め られていない. 自験例は発育形態が内腔は隆起を伴う 潰掦形態を呈しているのにもかかわらず，壁外への突 出も認められ，形態的にも稀な症例であり診断を迷う 一要因であった. 組織学的に迷入膵の癌化による可能 性も考えられたが9, 摘出組織内にランダルハンス島, 腺房細胞，膵導管の存在は認められず，迷入膵由来の 癌化の可能性は低いと考えた。

十二指腸球部癌に対する手術法においては，一般的 には膵頭十二指腸切除が施行されているが1) 7)，十二 指腸部分切除でよいとする報告もみられ委，明確な基 準はなく，個々の症例についてそれぞれ判断している のが実情である ${ }^{3}$. 自験例において, 術式は患者の術後 QOL を第一とし, 十二指腸部分切除を施行し,リンパ 節郭清は十分行っていない.リンパ節転移の有無によ る転帰についての報告は未だ少ないが15) 7)，mp 以深 の進行癌の場合はリンパ節転移が多く，膵頭十二指腸 切除および十分なリンパ節郭清が望ましいといわれ

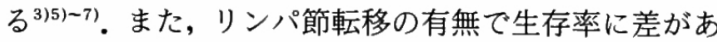
るという報告もある．われわれの症例は, 病理組織検 査にて漿膜露出, リンパ節への転移が認められており, 根治性を求める上では手術法について問題があると思 われ，今後㛜重な経過観察が必要と思われる。 
結語

十二指腸粘液癌の手術症例を経験した．形態的にも 珍しいものであったため，若干の考察を踏まえて報告 した。

なお、本論文の要旨は第66回日本臨床外科学会絰会 $(2004$ 年10月, 岩手) で報告した。

\section{文嶰}

1) 齊藤修治, 遠藤 格, 熊本宣文他：治痹切除が可 能であった第 4 部の十二指腸癌の 1 例. 日消外会 誌 $34: 485-489,2001$

2）魚谷英之, 沢田石勝, 堀川直樹他：原発性十二指 腸球部進行癌の 1 例. 癌の臨 $44: 645-650,1998$

3）佐々木誠, 押淵徹, 浜崎宏明他：原発性十二指 腸球部噖様腺癌の 1 例. 日消外会誌 $24: 2419-$ 2423,1991

4) 横浜吏郎, 石関哉生, 田森辟介他：十二指腸原発 mucinous papillary adenocarcinoma $の 1$ 例. 消 画像 $4: 233-239,2002$

5）大西一朗, 小西孝司, 荒川 元他: 原発性十二指 腸進行癌切除症例の検討. 日臨外会誌 $61: 1675$ $-1679,2000$

6）児玉久光, 吉本晃宏, 内田陽子 : 原発性十二指腸 球部癌の 1 例. 外科 $65: 1741-1744,2003$

7) 藤倉博之, 浦上 淳, 岩本末治他: 原発性十二指 腸癌 7 症例の検討. 川崎医会誌 $28: 137-142$, 2002

8）伊藤忠雄, 小西啓夫, 麦谷達郎他: 著明な壁外進 展により回腸に穿破し瘦孔を形成した横行結腸粘 液癌の 1 例. 日消外会誌 $34: 505-509,2001$

9）和久利彦, 上塚大一, 渡辺直樹他：迷入膵上り発 生した粘液産生十二指腸癌の 1 例. 日消外会誌 $29: 2289-2293,1996$

\title{
A CASE OF MUCINOUS CARCINOMA OF THE DUODENUM WITH ABDOMINAL TUMOR
}

\author{
Mikihiro KANOU and Jyunji MURASHITA* \\ Department of Surgery, Mazda Hospital \\ -Department of Surgery, Saijyo-central Hospital
}

An 83-year-old man was admitted for right abdominal pain and an abdominal tumor was detected by CT scan, and endoscopic study revealed an irregular-shaped ulcer in the duodenal bulb. Endoscopic biopsy of the ulcer showed a histological diagnosis of adenocarcinoma. The duodenal tumor was partially resected. Macroscopically, the tumor which had mucus, was seen from the duodenal bulb to the second portion, with a Borrmann II appearance.

Histologically, it was diagnosed as mucinous carcinoma accompanied with adenocarcinoma. Mucinous carcinoma of the duodenum is rare in gastrointestinal carcinoma. Our case showed uncommon tumor growth of extramural progression of duodenal mucinous carcinoma. 